\title{
Queer Faith: Reading Promiscuity and Race in the Secular Love Tradition. Melissa E. Sanchez. \\ Sexual Cultures. New York: New York University Press, 2019. xii + 338 pp. \$99.
}

What if the idea, long regarded as received truth, that Christianity sets out monogamy as the only lawful way to be married-indeed, as synonymous with love itself-is not historical truth at all but a rumor, a phantasm, a copy with no original? Of all the political flashpoints in early Christian thought, monogamy might at first seem less urgent than, for example, the raging interpretive battle over the Pauline position on homosexuality. However, with Queer Faith, a strangely beautiful, genre-bending interrogation of Renaissance poetry's conversation with Christianity, Melissa Sanchez insists that monogamy and its foil, promiscuity, are absolutely central to understanding the origins of our culture's ideology of love, and hence of virtue. Diving deep into the poetic figurations of love on offer in secular poetry and Christian theology — and devoting the same close attention to language in both-Sanchez uncovers a shadow history in which Christianity constructed human love as a primally promiscuous force, forever errant and falling away from its desired objects; human will as inherently divided against itself; and human faith as fundamentally unfaithful.

From Petrarch's dramatization of love as a version of Paul's and Augustine's failed, disobedient faith in his Rime sparse sonnet sequence, Queer Faith traces the debate over the impossibility of a faithful love through Renaissance poetry and Reformation thought, wandering into some surprisingly queer alternatives. Not only were the natures of human and divine love anything but settled matters in the Renaissance, Sanchez finds in even the most iconic documents used to enforce and elevate an ideal of love as willed, unitary, and single-object-oriented-e.g., Paul's first epistle to the Corinthians-a deeply constitutive theology of perversity. Not a redemption of monogamous, married sex (as in liberal rights discourse today-e.g., Anthony Kennedy's language in Obergefell) but an acknowledgment that obedience to God's command to want only the right things, in the right way, is fundamentally impossible. Isn't the human estate, as Sanchez says of Petrarch on Augustine, "not being able to want what one wants to want, to know what one really wants, or to stop wanting what one does not want to want" (46)?

Queer Faith is revelatory in elaborating how the phantasm of monogamy has conditioned such fundamental political values as loyalty and freedom. What does it mean to be faithful to a person? An idea? A vocation? Or, as Sanchez ponders in the coda, a scholarly field? And, crucially, which people have been seen as having the capacity to be faithful, or the standing to command faithfulness? Sanchez makes clear that the nascent value system of whiteness plays a central role in how monogamy came to be an ideal at all. Chapter 2, "The Color of Monogamy," traces the racializing history of the concept, first used to define Protestant marriage customs against the polygamy of religious 
others. Monogamy dovetails later with ideologies of companionate marriage, which derive in turn from classical homosocial friendship. A relation predicated on likeness and self-sovereignty, classical friendship is constitutively white-in Aristotle, limited to male citizens who are "by nature free" — and racial exclusivity is key to how it continues to function, as a kind of mitochondrial ancestor-ideology within heterosexual companionate marriage, to define virtuous relationships according to a standard of whiteness.

Sanchez approaches faith as "a form of fantasy about ourselves and our objects of desire” (25), reading Petrarch, Shakespeare, Paul, and Calvin alike as texts that make worlds out of language, positing imaginative and instructional models of how desire works. While meticulously faithful to early modern theological conflicts, Queer Faith defies the distancing of periodization. The debate in which it intervenes is two thousand years long and includes the present. It belongs in a canon with Mark Rifkin's When Did Indians Become Straight? (2010), Julian Carter's The Heart of Whiteness (2007), Stephanie Coontz's The Way We Never Were (1992), and Hortense Spillers's "Mama's Baby Papa's Maybe: An American Grammar Book" (1987): works that debunk the ahistorical rhetorics of always-ness used to enforce white cis-heterosexual patriarchal models of family, sexuality, and morality.

Queer Faith also defies methodological monogamy, having theological history cheat with queer theory while both are seeing poetics on the side. Its carefully contextualized historical readings flirt with what Madhavi Menon calls "queer universalism.” In making visible the debt to early Christian theology underpinning the psychoanalytic model of desire as lack, Sanchez uncovers a core of ambivalence, irrationality, and amorality - a constitutive kernel of antisocial queerness — at the heart of modern, Western ideologies of selfhood. At the same time, Sanchez refuses easy or liberatory political answers, acknowledging the difficulty of living within the ties that bind and the existential problem of how to square an ideal of the good with the vagaries of desire.

Harm has been done, Sanchez intimates in the book's powerful sections on modern sexual politics, by monogamist interpretations of past writing about love. Lives and families have been fractured; the ambit of morality has been absurdly narrowed to a single relational form that was imagined as impossible all along. In the afterlife of this copy with no original, people have been educated to value women and girls according to their sexual purity, to demonize the vast plurality of erotic practices and relations besides monogamy, and to see whiteness as entailing superior sexual morality. Social capital has been conditioned on accepting these valuations and perpetrating them on others in turn. Melissa Sanchez's Queer Faith argues that it could have been-and still could be-otherwise. 